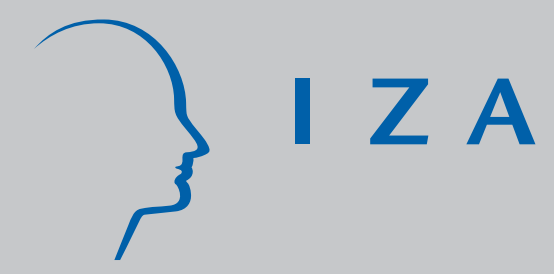

IZADP No. 2622

Worker Mobility, Displacement, Redeployment and Wage Dynamics in Italy

Bruno Contini

Claudia Villosio

February 2007 


\title{
Worker Mobility, Displacement, Redeployment and Wage Dynamics in Italy
}

\author{
Bruno Contini \\ University of Torino, LABORatorio R. Revelli \\ and IZA \\ Claudia Villosio \\ $R \& P$ and LABORatorio R. Revelli
}

Discussion Paper No. 2622

February 2007

IZA

P.O. Box 7240

53072 Bonn

Germany

Phone: +49-228-3894-0

Fax: +49-228-3894-180

E-mail: iza@iza.org

\begin{abstract}
Any opinions expressed here are those of the author(s) and not those of the institute. Research disseminated by IZA may include views on policy, but the institute itself takes no institutional policy positions.

The Institute for the Study of Labor (IZA) in Bonn is a local and virtual international research center and a place of communication between science, politics and business. IZA is an independent nonprofit company supported by Deutsche Post World Net. The center is associated with the University of Bonn and offers a stimulating research environment through its research networks, research support, and visitors and doctoral programs. IZA engages in (i) original and internationally competitive research in all fields of labor economics, (ii) development of policy concepts, and (iii) dissemination of research results and concepts to the interested public.
\end{abstract}

IZA Discussion Papers often represent preliminary work and are circulated to encourage discussion. Citation of such a paper should account for its provisional character. A revised version may be available directly from the author. 


\section{ABSTRACT}

\section{Worker Mobility, Displacement, Redeployment and Wage Dynamics in Italy}

We investigate various stylized facts on wage growth, labor mobility and firm size, to date unexplored in Italy. Using a wage decomposition that allows to separate "individual premiums" from firm-effects, we ascertain: (1) whether movers are better off than stayers; (2) whether firm size affects the outcome of workers' mobility across; and (3) the extent to which did job displacement and redeployment inflict wage losses to downsized workers. The sample - a closed panel of full-time male employees, aged 20-50, at work from 1986 to 1991 - is drawn from the employer-employee linked database WHIP (Work Histories Italian Panel).

JEL Classification: J62, J63

Keywords: job mobility, wage growth, displaced workers

Corresponding author:

Bruno Contini

LABORatorio R. Revelli

Collegio Carlo Alberto

Via Real Collegio 30

I-10024 Moncalieri (To)

Italy

E-mail: bruno.contini@unito.it

\footnotetext{
* This is a widely revised version of a study that has had a long gestation period. Some of the early revisions have been written while visiting the Institute for Industrial and Labor Relations, Princeton University in the spring of 2000 , where Contini was given generous hospitality. We have benefited from comments received after presentations of this version at Princeton, Torino, Padova and Aarhus. In particular, we wish to thank $\mathrm{O}$. Ashenfelter and $\mathrm{H}$. Farber. This research has been carried out thanks to grants by MUIR (1999 and 2001) to a inter-university research project "Labor mobility and wages: measurement problems, analytical tools, policy evaluation", coordinated by U. Trivellato of the University of Padua. Very valuable research assistantship has been provided by Roberto Quaranta and Matteo Morini.
} 


\section{Introduction}

There is a long standing interest in the influence of employer size on wages. In this paper we investigate the relation between wage levels and growth, labour mobility and firm size among Italy's dependent workers between 1986 and 1991. This is not a study aimed at testing theories of job matching and individual choices between staying on the present job or moving to a new one. It is a descriptive paper in which we intend to ascertain: (1) whether job changes have improved the position of movers vis-à-vis the stayers' over the five-year observation window; (2) whether firm size affects the outcome of workers' mobility across jobs and firms; and (3) to what extent did job displacement and redeployment inflict wage losses to downsized workers. All (or nearly all) the precautions against the risk of selection bias have been taken, as explained below.

We use an employer-employee linked database developed from Italian Social Security (INPS) administrative sources, from which we build a closed panel of full-time male employees of all industries of the private sector, aged 20-50, at work both in 1986 and 1991. Exclusions relate to: (i) women, in order to have better control over individual characteristics; (ii) the construction sector, in view of its seasonal characteristics; (iii) individuals aged over 50, whose (possible) retirement decision would interfere with the analysis of job-to-job changes.

As in most employer-employee linked databases, we have no direct information on quits vs. layoffs. ${ }^{2}$ We therefore proxy voluntary vs. involuntary job changes on the basis of the past and future employment history of firms from which the change originates. This is taken up in detail in par. X.

Investigating the comparative advantage of movers vs. stayers, not on impact -as is done in many studies on job change ${ }^{3}$ - but over a relatively long observation window, suggests that the relevant "movers" are those who do switch from one job to another (eventually going through unemployment spells), and not those who end up in long term unemployment or leave the labour market altogether. For this reason we choose to work with a closed panel of individuals, observed on the workplace from the beginning to the end of the study period. This choice allows also to finesse the main problems of unobserved heterogeneity, which would inevitably occur had we opted for open panel estimation where - as will be discussed in section 3.1- attrition is nonrandom and always present.

In Section 1 we present a short survey of the literature. Section 2 provides some background information and descriptive statistics on mobility and wages. Section 3 describes a decomposition of individual wage growth, and the specification of the econometric model. The main results are presented in Section 4: in first place we discuss the impact on wage growth of job changes across firm size, and the size differentials between stayers and movers; in second place the effect of unemployment spells and of the frequency of job changes; in third place we question how initial conditions may affect estimation. In Section 5 we investigate: (i) the extent to which worker displacement and redeployment inflict wage losses to downsized workers; (ii) the magnitude of the gain accruing to voluntary job changers. Section 6 concludes.

\footnotetext{
2 The distinction between quits and layoffs is neat in principle, always problematic in practice. Interviewed individuals will seldom declare that they have been laid-off, as it may be perceived as a self-inflicted stigma. Firms too have no incentive to report layoffs. Even in the course of downsizing, firms prefer to report quits, which may be "technically" correct when dismissed workers are offered severance payments.

${ }^{3}$ See M. Burda and A.Mertens (2001), S. Nickell et al. (2002), H.S. Farber (1993).
} 


\section{A quick look at the literature}

A rich body of empirical studies on various aspects of mobility and wage dynamics has grown in the Nineties, as databases containing information on workers, jobs and firms have become available.

In one of the earlier studies on the United States, Brown and Medoff (1989) find no impact of firm size on wages for job-stayers, but significant size differentials among movers. This is confirmed by P. Gottschalk (2001), who suggests that in the United States (1986-93) mean wage growth between jobs is large in comparison to wage growth while working for the same employer, especially for less educated workers. R. Winter-Ebner and J. Zweimuller (1999) study wage changes of workers who move between firms of different size classes in Switzerland: the wage growth of job changers from small to larg(er) firms is significantly higher than that of job changers in the opposite direction. However, if worse working conditions are reflected in higher, utilityequalizing wages, these authors find no evidence for the hypothesis that larger enterprises provide less pleasant working conditions than small businesses. H. Farber (1993 and 1997) looks into the cost of job losses after displacement, finding that job losses adversely affects workers' earnings in many ways. Employment probabilities are reduced and an increased probability of working part-time yields lower earnings both through shorter hours and lower wage rates. The decline in real weekly earnings between the pre displacement job and the post displacement job averages about $13 \%$ for all reemployed displaced workers and about $9 \%$ for workers displaced from full-time job who are reemployed on full time job. Burda and Mertens (2001) find that wages of displaced workers in Germany decline slightly upon reemployment. The lowest wage quartile (where displacement is concentrated) gains slightly, while losses for the upper three quartiles are comparable to the US evidence.

Hartog and Van Ophem (1994) study wage growth of certain groups of employees discriminating between mobile and non-mobile employees, and between voluntary and non-voluntary job changes; C. Flinn (1986) analyses the intertemporal structure of wages for young workers separately for movers and stayers. He presents evidence that unobserved worker-firm heterogeneity is an important component in the wage growth of young workers.

Evidence on real wage losses consequent on unemployment is provided for the UK by S. Nickell et al. (2002): estimated hourly losses amount to $10-20 \%$ during the first year from rehiring after the first unemployment spell. Longer duration spells are associated to significantly greater losses.

A somewhat different question is posed by P. Gautier et al. (2002): who gets crowded out during downturns in the Netherlands ? Their findings are that at each job level it is mainly the lower educated workers who leave during downturns.

\section{Background and descriptive statistics}

\subsection{Data used}

Our analysis is based on individual data from the Administrative Social Security (INPS) archives. We use a panel of workers matched to their firm of affiliation of approximately 100,000 workers each year from 1985 to 1991. From this panel we select a sample of 30167 full-time male workers, employed both in 1986 and in 1991 in the manufacturing and service sectors, and aged 20-50 in 1986. We find two groups:

(i) 20526 stayers $(68 \%)$, employed at the same firm from the beginning till the end of the observation period (not necessarily uninterrupted spells) 

of all movers go through only one job-switch, $36 \%$ undertake more than two ${ }^{4}$.

Moves are more frequent among young workers, and decrease with ageing of the working force. Differences between blue-collars and white-collars are slight. Almost half of the employed bluecollars aged 20-30 experience at least one job change in the 1986-91 period. ${ }^{5}$

The frequency of job changes is, not surprisingly, inversely proportional to firm-size: $44 \%$ of workers employed at small firms in 1986 change jobs in the observation period; this frequency falls to $33 \%$ for workers employed at mid-size firms, and to $21 \%$ for workers of large firms.

Most of the job changes take place within the same industries, suggesting that industry-specific human capital and experience are relevant: only few workers (less than 5\%) move from manufacturing to service industries, slightly more in the opposite direction.

While the majority of job changes take place among firms of equivalent size, job switches towards larger firms are more frequent than moves in the reverse direction. The pattern is clearly visible in manufacturing, less so in the service industries, where average firm size is less than half that of manufacturing..

Tab. 1 Frequency of job changes 1986-91 across firm size (9641 movers)

\begin{tabular}{|l|r|r|r|}
\hline \multicolumn{5}{|c|}{ Manufacturing } \\
\hline & Small & medium & large \\
\hline small $(<20)$ & 56.2 & 33.7 & 10.1 \\
\hline medium $(20-500)$ & 20.8 & 59.0 & 20.2 \\
\hline large $(>500)$ & 3.0 & 22.8 & 74.2 \\
\hline \multicolumn{5}{|c|}{ Services } & large \\
\hline \multicolumn{2}{|c|}{ Small } & medium & 7.1 \\
\hline small $(<20)$ & 69.2 & 23.8 & 32.3 \\
\hline medium (20-500) & 22.7 & 45.0 & 57.3 \\
\hline large $(>500)$ & 5.1 & 37.6 & \\
\hline
\end{tabular}

Preliminary explanations of the patterns of job change are provided by well known stylized facts about working conditions, tenure and pay at various firm-types. Ranking firms by size, the following emerge clearly: (i) large firms pay better wages than small ones; (ii) mean tenure at large firms is higher than at small enterprises. ${ }^{6}$ The former is in line with predictions from efficiency wage theory; the latter with two well known facts: (1) turnover is physiologically high among small firms, also a consequence of survival rates which are much shorter compared to larger businesses; (2) job hierarchies are longer and more articulated in large firms, where mobility often takes place along internal lines ${ }^{7}$.

In principle, therefore, workers may wish to move from a small to a large firm, as this would ensure at the same time a higher pay and a more stable career. ${ }^{8}$ On the other hand, job quality is

\footnotetext{
${ }^{4}$ Mobility in this panel is not comparable to the separation and association rates estimated for the Italian economy at large (Contini et al., 1996): our current database consists of a closed panel of individuals employed as dependent workers both in 1986 and in 1991, as opposed to open panels which include all exits from and entry to employment. The mean annual separation rates observed from open panels from the same administrative source are in the order of $34 \%$ of dependent employment in the private sector. Not surprisingly, the overall separation rate is many times higher than the frequency of job changes observed in this closed panel.

${ }^{5}$ Since the mid-Eighties through the Nineties young people (18-29) were eligible to be hired under 2-year "training-and-work" contracts (CFL), not subject to renewal. At the end of the contract period, either the contract was transformed into a permanent one, or a job-change was necessary.

${ }^{6}$ See B. Contini et al.(1996)

${ }^{7}$ Cfr. B. Contini and R. Revelli (1997)

8 This is also suggested by the shared opinion that in Italy small manufacturing firms play the role of training-on-the-job for young workers who start their career in a small establishment, and then move on to larger firms once the learning phase is completed. Such a prior cannot, however, find but mild support in closed panels like ours: at the aggregate level there are equilibrium conditions of the firm size distribution
} 
another important factor determining job changes. This, however, cannot be directly observed and is problematic to ascertain. It is, sometimes, suggested that small firms often offer more pleasant working conditions than large firms: the smaller environment makes it easier to develop friendly relations with colleagues, the style of supervision may not be as rigid as in large organizations, tasks may not be as repetitive, working hours may often be more flexible. Thus there could be a negative association between firm size and job quality, and this may help to explain why sizeable job-to-job flows are observed from larger to smaller firms even when the pay differential is modest or negative, or when there is no indication that one's job is at risk of layoff or termination.

\subsection{Wage levels and growth rates among movers and stayers}

Tab. 2 contains means and standard deviations of monthly wages of movers and stayers in 1986 and 1991. Average nominal wage growth $1986-91$ is $60 \%$. Italy's consumer price index increased by 32 p.p. between 1986 and 1991. Thus real wage growth in our sample is quite substantial, almost $30 \%$ in the 5 -year observation period.

Tab. 2 Monthly (nominal) wages in 1986 and 1991 and wage growth rate 86-91

\begin{tabular}{|r|l|r|r|r|r|r|r|r|}
\hline & & \multicolumn{3}{|c|}{ Movers } & \multicolumn{3}{|c|}{ Stayers } & $\begin{array}{l}\text { Mean } \\
\text { advantage }\end{array}$ \\
& & $\mathbf{N}$ & Mean & Dev.std & $\mathbf{N}$ & Mean & Dev.std $\begin{array}{l}\text { stayers vs. } \\
\text { movers }\end{array}$ \\
\hline & Wage 86 & 9641 & 1731.2 & 548.2 & 20526 & 1906.7 & 604.2 & +10.1 \\
\hline & Wage 91 & 9641 & 2805.2 & 1138.3 & 20526 & 3042.3 & 1184.5 & +8.4 \\
\hline & $\begin{array}{l}\text { Nominal wage } \\
\text { growth }\end{array}$ & 9641 & 0.62 & 0.42 & 20526 & 0.60 & 0.3 & \\
\hline
\end{tabular}

The mean initial wage (1986) of the stayers is more than 10 p.p. higher than that of the movers (before moving) in all groups; the mean final wage (1991) of the stayers is 8.4 p.p. higher than the movers'. On the other hand, the movers' wage growth is marginally higher than the stayers', especially at young age and mainly for the white-collars.

Given these premises, the following are the questions we intend to answer:

1 Are there sizeable differentials between stayers and movers ?

2 Does firm size affect wage growth for movers (across firms of different size) and stayers as much as it determines cross-sectional wage level differentials ?

3 Are frequent movers better off than one-time movers?

4 Do intervening unemployment spells negatively affect wage growth ?

5 Are there downsizing and redeployment effects on wage growth ? Are there significant differences between what we identify as voluntary and involuntary job changes ?

that must hold. If worker flows from small to large firms were steadily much larger than flows in the opposite direction, the observed firm size distribution would rapidly degenerate. It does not because each year newborn small firms enter the market, often employing young workers. But in a closed panel like ours these flows are not observable. 


\section{MODEL SPECIFICATION}

\subsection{Open vs. closed panel estimation}

Exploration of the database reveals that attrition is considerable and all but a random event: about one third of the workers present in 1986 drop out of the panel by 1991. Empirical evidence reveals that the vast majority of those who leave the panel - recall that workers approaching retirement age are not present - end up in states with negative economic connotation (unemployment, shadow economy, rarely out of the labour force except school re-entrants), some move into selfemployment, but for very few (less than $3 \%$ of those whose outcome is observable) does the move appear to be moderately successful. Such transitions would introduce a vast amount of unobserved heterogeneity in the analysis, should we decide to opt for open panel econometrics. As was explained at the outset, the principal aim of this paper is to ascertain whether movers are better off than stayers over a relatively long observation period, and not on impact. The relevant "movers" for this type of analysis are those who do switch jobs across firms, not those who become long term unemployed or labour market dropouts or move to the fringe of the market. Such movements would introduce a downwards bias in our estimates, that we definitely intend to avoid.

Our sample includes, therefore, one observation for each individual in the panel. Thus, while there is no room for panel estimation with unobservable, time-invariant, individual effects, we cannot do away with initial conditions that could influence the wage growth in the five-year period 1986-91. Our choice for a proxy of initial conditions is the i-th individual's relative wage in 1986, i.e. the ratio between $w(i, 86)$ and the average wage 1986 of all individuals belonging to the same cell (age $x$ industry $x$ skill level). To the extent that one's relative initial wage reflects also individual characteristics, this approach ought to yield satisfactory results ${ }^{9}$. To these results, and to the consequences of possible endogeneity of such proxy, we shall return after the presentation of the main estimates.

\subsection{The model}

Let $W(i ; j k)$ be the wage change (1986-91) for the i-th individual who has moved from firm-type $j$ (in 1986) to firm-type $k$ (in 1991). If he/she is a stayer, then $j=k$. Firm-types refer here to size and industry.

If firm characteristics have an impact on wage differentials, the following decomposition is of interest:

$$
W(i ; j k)=\left(\frac{w_{91}(i ; k)}{w_{86}(i ; j)}\right)+\left(\frac{\bar{w}_{91}(k)}{\bar{w}_{86}(j)}\right)-\left(\frac{\bar{w}_{91}(k)}{\bar{w}_{86}(j)}\right)-1
$$

where

$\frac{\bar{w}_{91}(k)}{\bar{w}_{86}(j)}=\hat{w}(j k)=$ mean $\quad$ wage $\quad$ growth $1986-91 \quad$ observed across firm-type j (origin) in 1986 and firm-type $k$ (destination) in 1991 has been added and subtracted to the expression for the wage change. The decomposition then reads as follows:

\footnotetext{
9 Another approach to the problem is that of Stewart, Swaffield (1998). To solve the problem of sample selection bias due to correlation across time between the unobservable, they use extra variables as instruments for the selection probability into the initial state.
} 
$W(i ; j k)=\left[\left(\frac{\bar{w}_{91}(k)}{\bar{w}_{86}(j)}\right)-1\right]+\left[\left(\frac{w_{91}(i ; k)}{w_{86}(i ; j)}\right)-\left(\frac{\bar{w}_{91}(k)}{\bar{w}_{86}(j)}\right)\right]=\hat{w}(j k)+w^{\prime}(i ; j k) \quad$ [II]

where :

$\hat{w}(j k)$ is the mean wage growth 1986-91 observed across firm-type $\mathrm{j}$ (origin) in 1986 and firmtype $\mathrm{k}$ (destination) in 1991;

$w^{\prime}(j k)=$ wage premium (or loss) accruing to the i-th individual in moving from firm-type $\mathrm{j}$ to firmtype $\mathrm{k}$, i.e. the extra-pay that individuals with certain characteristics are able to gain (or lose) over the mean wage change $\hat{w}(j k)$.

That is to say:

"total" individual wage growth 1986-91 $=\mathbf{W}(\mathbf{i} ; \mathbf{j k})=\hat{\mathbf{w}}(\mathbf{j k})+\mathbf{w}^{\prime}(\mathbf{i} ; \mathbf{j k})=$ =mean wage growth across firms of origin and destination (firm effect) + wage individual premium

The total wage growth associated to a move from firm-type $j$ to firm-type $k$ is given by the sum of two elements: the mean pay differential between the firm of origin in 1986 and that of destination in 1991 (firm effect), which does not depend on the workers' individual characteristics, and the individual premium that reflects various characteristics of the match, i.e. determined by the interaction of both workers' and firm's attributes.

The individual premium $w^{\prime}(i ; j k)$ may be expressed as a linear function of $X$ exogenous regressors of various types and residuals:

[1] $\quad w^{\prime}(i ; j k)=B^{\prime} X^{\prime}+B^{F} X^{F}+u$

where the superscripts $\mathrm{I}, \mathrm{F}$, denote regressors associated respectively with individual characteristics and firm characteristics.

Likewise, with no loss of generality, we may have the mean wage growth between firms of origin and destination $\mathrm{w}^{\wedge}(\mathrm{jk})$ written as another linear function of the same $\mathrm{X}$ regressors and residuals:

$$
w^{\wedge}(j k)=b^{\prime} X^{\prime}+b^{F} X^{F}+w
$$

where all the $b^{\prime}$ (reflecting purely individual characteristics) will be equal to zero.

"Total" individual wage growth is written as the sum of two linear functions of the same regressors:

$$
w(i ; j k)=\left(B^{\prime}+b^{\prime}\right) X^{\prime}+\left(B^{F}+b^{F}\right) X^{F}+(u+w)
$$

We perform separate estimation of both [1] and [3]. From the estimates of the three sets of $(B+b)$ and $B$ coefficients, we may obtain indirect estimates of $b$. The latter provide additional conditions for identification. In particular, we expect the estimates of $\left(B^{\prime}+b^{\prime}\right)$ to be approximately equal to $B^{\prime}$, implying $b^{\prime}=0$.

In the estimation of the individual premium [3], we take out firm effects from total wage growth $\mathrm{w}(\mathrm{i} ; \mathrm{jk})$ by subtracting $\left[\frac{w 91(k)}{w 86(j)}\right]$. The ratio $\left[\frac{w 91(k)}{w 86(j)}\right]$ is constructed controlling for: 1-digit industry, firm size, geography, skill category. We are unable, however, to control for performance and market related variables. Thus, their impact cannot be removed from the individual premium $\mathrm{w}^{\prime}$ 
(i;jk). This affects also $w^{\wedge}(j, k)$, calculated as difference, which denotes the firm effect. Given the structure of our data, it is probably safer to refer to the latter simply as "residual effect", rather than "firm-specific effect" as would be appropriate with ideal data ${ }^{10}$.

Let us now turn to the specification that we intend to estimate. Estimation of [1] and [3] is performed on two skill groups (Blue and White collars). The regressors are as follows (all the * are 0-1 dummies) :

$\mathbf{X}^{\mathbf{1}}$ The individual characteristics controlled for include proxy for initial condition, age, possible unemployment spells and a set of dummies, activated only for movers that catch the characteristics of mobility ${ }^{11}$.

Spells of unemployment may be observed for movers between successive jobs, and for stayers if their tenure is interrupted. The longer the spell, the higher the reduction of one's earning potential as a consequence of loss of visibility in the job market and/or loss of working ability.

Unfortunately education is not observable. This is a problem, but not a major one safe for young workers $^{12}$. We find indirect confirmation of this hunch in section 4.4 , where we find that individual endowments (including education) have an influence only among young and manual workers and do not show up among white collars whose hiring conditions depend more to collective bargaining agreements and less to educational attainment.

$\mathbf{X}^{\mathbf{F}}$ Firm characteristics include industrial 2-digit classification, geography, firm size, and changes across firm size ${ }^{13}$.

For each branch 9 dummy variables denote job-changes involving movements across firms classified by 3 size classes, separately for manufacturing and services. We distinguish small firms (<20 employees), medium firms (20 -200 employees ) and large firms ( $>200$ employees ). Thus we have 3 × 3= 9 "types" of job-change. The associated variables are activated as follows:

10 The problem may be seen as follows. Let $F$ be a vector of firm performance and market related variables that affect $w^{\wedge}(j, k)$. The system [1] - [3] is then written for short:

[1'] $\quad w^{\prime}(i ; j, k)=B X+u$

[2'] $\quad w^{\wedge}(j \cdot k)=b X+c F+w$

[3'] $\quad w(i ; j, k)=(B+b) X+c F+(u+w)$

If $F$ is not available, it will be omitted from [3'], and the OLS estimate of $(B+b)$ will be biased, converging to $(B+b)+c[\operatorname{cov}(X, F) / \operatorname{var}(X)]$. Thus the firm effect $b$, retrieved from [1'] and [3'], will be itself biased, unless $X$ and $F$ are uncorrelated.

$11 \mathrm{X}^{\mathrm{I}}$ regressors
\begin{tabular}{|l|l|}
\hline INEQ 86 & initial (1986) relative wage (proxy for initial conditions) \\
\hline AGE & Age \\
\hline UN-MOV & unemployment spell between jobs (in months), movers \\
\hline UN-STA & unemployment spell between jobs (in months), stayers \\
\hline MOV-2 $(*)$ & 2 job changes in the observation period \\
\hline MOV-3 $(*)$ & 3 job changes in the observation period \\
\hline MOV-4 $(*)$ & more than 3 job changes in the observation period \\
\hline DAV $\left(^{*}\right)$ & $\begin{array}{l}\text { occupational upgrading, involving a contract change (from blue to white collars } \\
\text { and from white to manager occupation) }\end{array}$ \\
\hline DZO $\left(^{*}\right)$ & geographical mobility \\
\hline
\end{tabular}

${ }^{12}$ Hartog and Van Ophem (1994) find that education has little or no effect on wage growth in relation to mobility. Bonjour and Pacelli (1998) tested on Swiss data the size and the direction of bias when age is used as a proxy for education and experience. They find that using age as a proxy for education leads to a small bias for men and full time working women.

${ }^{13}$ Our firm data are rich in some respects (in addition we have also information on: employment and earnings history by skill level and size, firm age, entry and exit flags), and weak in others. In particular, we have no data on performance, market power, financial structure. 


$$
D(i ; j k)=\quad \begin{array}{ll}
1 & i \text {-th individual moves from firm-type } j \text { to firm-type } k \\
0 & \text { otherwise }
\end{array}(\mathrm{j}, \mathrm{k}=1,2,3)
$$

If the $\mathrm{i}$-th individual is a "stayer" none of the $\mathrm{D}$ dummies are activated ${ }^{14}$.

Additional controls are provided by variables related to job changes, which we place among the $X(I)$ regressors: frequent job changes may reflect a positive attitude towards job search, and have a positive impact on wages. There could be, however, decreasing returns beyond a certain amount of job-switching, which our specification allows to catch.

The issue of voluntary and involuntary job changes (downsizing and redeployment) is discussed in section 5 .

\subsection{Estimation}

The equations object of estimation are [1] and [3], whose residuals are correlated. In fact: $\mathrm{E}[\mathrm{u}(\mathrm{u}+\mathrm{w})]=\mathrm{E}\left(\mathrm{u}^{2}\right)=\operatorname{var}(\mathrm{u})$

if $u$ and $w$ are orthogonal, as can be safely assumed.

In principle, therefore, we have a case of seemingly unrelated regressions, The two equations have, by construction, identical regressors: thus OLS will yield the same estimates as SURE.

\subsection{Identification}

By separately estimating equations [1] and [3], we have conditions for identification: the coefficients $b^{\prime}$ associated to individual characteristics $X^{\prime}$ ought to be zero in equation [2], explanatory of the wage growth attributable to firm effects only. Thus, we expect the estimates of $\left(B^{\prime}+b^{\prime}\right)$ to be approximately equal to $B^{\prime}$, implying $b^{\prime}=0$.

F-tests of the above null hypothesis are performed on the coefficients of all the $X^{\prime}$ variables (10 in all) estimated in equations [1] and [3], in two specifications, one for each occupational category. Only in one in twenty replications of the test, is the null rejected; in three cases acceptance is at the margin of significance. We deem this to be a good test of identification ${ }^{15}$.

\section{THE RESULTS}

We report here only the main results of OLS estimation. The full set of results are available upon request. Estimation is performed separately for each skill-group, the dependent variable being individual wage growth over the horizon 1986-91. Age and age square are introduced as additional

${ }^{14} \mathrm{X}^{\mathrm{F}}$ regressors

Activated for movers and stayers:

\begin{tabular}{|l|l|}
\hline R1 --> R8 $(*)$ & industrial sector \\
\hline SMALL - LARGE $(*)$ & firm size 1986 \\
\hline NOV-NES-SUD-ISO $(*)$ & 4 geographical dummies (firm location) \\
\hline
\end{tabular}

Activated only for movers

\begin{tabular}{|l|l|}
\hline DM1 --> DM9 $(*)$ & job-change across firm size (manufacturing) \\
\hline DS1 --> DS9 $(*)$ & job-change across firm size (services) \\
\hline
\end{tabular}

15 A complete set of results is available on request. 
controls and turn out significant, respectively negative and very slightly positive, as expected from the hump-shaped profile of wage levels vs. age. We have also estimated the model by three age groups, but do not report them here as differences are very slight. The only exception relates to the coefficients that catch the impact of job change across firms of different size: these are somewhat more sensitive to age, but inter-age variability is not indicative of any clear pattern.

\subsection{Job switches across firm size}

Our prior is that job switches across firms of different size may have an important impact of their own on wage growth.

The relevant information is compressed in the following ( $3 \times 3)$ matrices of OLS estimated coefficients (all multiplied by 100) associated to job-switches across firms classified into three size classes. The associated dummies are activated only for movers, the stayers being the benchmark:

S "small" firms (less than 20 employees)

M "medium" firms (20 - 200 employees)

L "large" firms ( > 200 employees)

Cells show a zero when the relative coefficient is non significantly different from zero.

Moving across the columns of each $3 \times 3$ table (from left to right) denotes the effect of a job switch ending in firms of increasing dimension. Moving across the rows (from high to low) catches a job switch originating from firms of increasing dimension. Thus in the North-East corner above the diagonal we have job-switches from small to large; in the South-West corner from large to small.

The first four tables (tables A1-A4 denominated "total wage growth") reports the $(B+b)$ coefficients of the 9 dummies related to the switches across firm size, estimated on [3]. The second group pf tables (tables B1-B4 denominated "individual premium") reports the same B coefficients (9 in number) estimated on [1]. 
Tab. 3 Wage gains due to job switches across firm of different size

\section{A) Total wage growth (equation I)}

Blue collars.

\begin{tabular}{|l|l|l|l|}
\hline \multicolumn{4}{|c|}{ A1. Manufacturing } \\
\hline From/To & $\mathrm{S}$ & $\mathrm{M}$ & $\mathrm{L}$ \\
\hline $\mathrm{S}$ & 0 & $12++$ & $22++$ \\
\hline $\mathrm{M}$ & $-5+$ & $4+$. & $7++$ \\
\hline $\mathrm{L}$ & $-18++$ & -5 & 0 \\
\hline
\end{tabular}

\begin{tabular}{|l|l|l|l|}
\hline \multicolumn{4}{|c|}{ A2. Services } \\
\hline From/To & $\mathrm{S}$ & $\mathrm{M}$ & $\mathrm{L}$ \\
\hline S & -2 & $11++$ & $33++$ \\
\hline M & -5 & 0 & 0 \\
\hline L & $-35+$ & $-33++$ & $9+$ \\
\hline
\end{tabular}

White collars

\begin{tabular}{|l|l|l|l|}
\hline \multicolumn{4}{|c|}{ A3. Manufacturing } \\
\hline From/To & $\mathrm{S}$ & $\mathrm{M}$ & $\mathrm{L}$ \\
\hline $\mathrm{S}$ & -11 & $12+$ & $33+$ \\
\hline $\mathrm{M}$ & 0 & $10++$ & $18+$ \\
\hline $\mathrm{L}$ & $27+$ & $23++$ & $14+$ \\
\hline
\end{tabular}

\begin{tabular}{|l|l|l|l|}
\hline \multicolumn{5}{|c|}{ A4. Services } \\
\hline From/To & S & M & L \\
\hline S & 0 & $14+$ & $62++$ \\
\hline M & 0 & $11+$ & 0 \\
\hline L & $28+$ & $10+$ & 10 \\
\hline
\end{tabular}

B) Individual Premium (equation III) Blue collars.

\begin{tabular}{|l|l|l|l|}
\hline \multicolumn{4}{|c|}{ B1. Manufacturing } \\
\hline From/To & $\mathrm{S}$ & $\mathrm{M}$ & $\mathrm{L}$ \\
\hline $\mathrm{S}$ & $12++$ & $6+$ & 0 \\
\hline $\mathrm{M}$ & $12++$ & $3+$ & $-10+$ \\
\hline $\mathrm{L}$ & 0 & 0 & $-9+$ \\
\hline
\end{tabular}

\begin{tabular}{|l|l|l|l|}
\hline \multicolumn{4}{|c|}{ B2. Services } \\
\hline From/To & S & M & L \\
\hline S & $7++$ & 4 & 0 \\
\hline M & $12+$ & 5 & $-25++$ \\
\hline L & 0 & $-24+$ & 0 \\
\hline
\end{tabular}

White collars

\begin{tabular}{|l|l|l|l|}
\hline \multicolumn{4}{|c|}{ B3. Manufacturing } \\
\hline $\begin{array}{l}\text { From/T } \\
\text { O S }\end{array}$ & M & $\mathrm{L}$ \\
\hline S & $19+$ & $17+$ & 22 \\
\hline M & $26++$ & $8+$ & 0 \\
\hline L & $49++$ & $21++$ & 0 \\
\hline
\end{tabular}

\begin{tabular}{|l|l|l|l|}
\hline \multicolumn{5}{|c|}{ B4. Services } \\
\hline From/To & $\mathrm{S}$ & $\mathrm{M}$ & $\mathrm{L}$ \\
\hline $\mathrm{S}$ & $35++$ & $10+$ & $46++$ \\
\hline $\mathrm{M}$ & $38++$ & $15++$ & -11 \\
\hline $\mathrm{L}$ & $81++$ & 0 & 0 \\
\hline
\end{tabular}

Significance of the coefficients are indicated as follows:

$0=$ coefficient non significant;

no asterisk $=90 \%$ significance

$(+)=95 \%$ significance;

$(++) 99 \%>$ significance

We emphasize the following :

(i) the decomposition yields qualitatively different results between manual workers and white-collars: while blue-collars often loose after a job change, and seldom succeed in "selling" their individual skills and personal characteristics, the white-collars often improve their earnings position from job changes, and, in addition, gain an individual premium. This provides strong evidence that wage growth (or loss) for manual workers is largely a consequence of firm-based wage policies, more than individual characteristics. For white-collars, instead, firm-based wage policies are less binding and individual characteristics often rewarded.

(ii) consequently, we find significantly larger coefficients in the white-collars' regressions (A.2 - A.4) than in the blue-collars' (A.1 - A.3). This simply means that mover-stayer differentials are bigger among white-collars: this is expected given the large variance of earnings of the latter (both cross-sectional and longitudinal), and the higher possibilities of climbing the hierarchical ladder. 
(iii) age matters only among the white-collars. While the estimated age and age square coefficients are highly significant in both equations, age has zero impact on wage growth among the blue-collars. Among the white-collars, instead, each year of age is worth about 1 p.p. in wage growth, with younger workers doing monotonically better than their older colleagues: average wage growth for a 25-year old individual is, ceteris paribus, over 20 p.p. higher than a 45-year old.

More specifically:

TOTAL wage growth (Tables A)

BLUE / job-switches "small- $\rightarrow$ large " (NE corner) yield positive coefficients, i.e. significant mover-stayer earning differentials. When job-switches occur in the reverse direction (SW corner: small- $\rightarrow$ large), wage growth is negative, i.e. job switches penalize the movers (A.1 and A.3 ). This pattern is a straight consequence of the strong correlation between earnings and firm size, and of the predictably modest career profiles of blue-collar workers.

WHITE / (A.2 and A.4) : job-switches in either direction yield positive differentials relative to stayers, regardless of the size of firms of origin and destination.

INDIVIDUAL PREMIUM (Tables B)

\section{BLUE}

Here we find a somewhat different pattern among the blue-collars: the majority are negative coefficients associated to moves "small $\rightarrow$ large" (NE-corner); mainly positive for moves from "large $\rightarrow$ small" (SW-corner).

Consider, for instance, a manual worker's switch from a medium-sized firm to a large one of the manufacturing sector: his total gain over a stayer (in the firm of origin) is 7 p.p. (TOTAL, tab. A). His individual premium depends on how large is the average wage differential for his skill group between the firm of destination and that of origin. If the average wage differential is larger than 7 p.p. it means that his individual characteristics are valued less than this average. The individual premium associated to such a move is estimated at -10 p.p. (implying that the differential $\mathrm{w}^{\wedge}(\mathrm{jk})$ must be of the order of 17 p.p.).

More generally, in the N-E corner of the PREMIUM matrices, we find mainly negative coefficients. As we have seen in tab. A (TOTAL) blue-collars who make "small $\rightarrow$ large" moves gain from the change compared to stayers. In addition they gain also in terms of expected job length. On the other hand, in view of the fact that average blue collars' wages paid by large firms are substantially higher than those paid by small firms, the premium associated to individual skills and personal endowment may turn out negative.

In the SW-corner, instead, we have manual workers who switch "large $\rightarrow$ small". TOTAL estimates suggest that, on average, they suffer a wage loss. Why, then, should these individuals move at all, considering that they also run the risk of facing a shorter tenure ? Aside from the possibility that they may be forced to make the change (discussed in section 5.1), we would expect the PREMIUM to be positive and quite sizeable. This is, indeed, what our estimates indicate: at times the individual premium is even larger than a positive TOTAL wage growth. Quite clearly, these movers succeed in having their individual expertise and skills recognized in the job change, inspite of firm wage policies that pull in the opposite way.

WHITE - Individual skills and endowment matter, instead, for the white-collars, adding to the positive outcome estimated in the TOTAL decomposition. Here too, this is particularly evident in the S-W corner associated to "large- $\rightarrow$ small" changes (and on the diagonal): the premium coefficient is often larger than the estimated (positive) total wage growth. Job changers who move into a smaller enterprise may be risking a shorter job tenure, but they appear to be well compensated by a substantial improvement in their earnings status and reinforced by the premium recognized to their personal characteristics. The magnitude of such premium is quite remarkable, 
especially in the service industries. These moves are likely to be the result of job-seeking while on-the-job by individuals endowed with valuable skills and experience, and free from the threat of being dismissed or transferred in years of recession.

In few cases the estimated premium is zero (never when the job change originates or ends up in a small firm), and only in one case do we find it negative (tab. B4. cell. $(2,3)=-11$ ). In this particular case, however, collective redeployment yields the necessary explanation, as will be seen in section 5.1 .

We do not display here the coefficients associated with firm effects. The pattern is very robust: all are positive above the main diagonal (N-W corner); all are negative below (S-E corner). The Ftest on the joint significance of these signs above and below the diagonal passes with flying colors. This result is not unexpected: the wage growth attributed only to firm effects is positive when job changes take place from smaller to larger firms, controlling for 1-digit industry and geographical location; it is negative when the direction of job change is reversed. Here too, the wage-size positive correlation overshadows all other effects.

\subsection{Unemployment spells}

One's absence from the panel between two employment spells indicates - with high probability periods spent in unemployment ${ }^{16}$. The length of such spells has a slight, but nonetheless significant, impact on total wage growth. The loss of wage growth at the end of the observation period is only 0.1 p.p. for each month spent in unemployment for the blue-collars, movers and stayers alike. A six-month unemployment spell between two successive jobs causes a 0.6 p.p. reduction of wage growth. Not surprisingly, the negative impact of unemployment spells is higher for white-collar movers, about - 0.4 p.p. for each month in unemployment, adding up to - 2.4 p.p. for a six-month unemployment spell, and -4.8 p.p. for a one-year spell. No impact, however, emerges for the white-collars who go through unemployment but get rehired in the same firm at the end of the spell. ${ }^{17}$

These results confirm the hypothesis that the careers of those who remain blue collars all their life are flat and unaffected by spells of unemployment, provided they are back on the job by the end of the observation period. On the other hand, and in line with explanations in term of specific human capital, a career interrupted by periods spent in unemployment does have an impact on the earning profiles of the white collars.

Tab. 4 The impact of intervening unemployment spells on wage growth (in p.p.)

\begin{tabular}{|l|c|c|c|c|}
\hline & \multicolumn{2}{|c|}{ 1 month } & \multicolumn{2}{c|}{ 6 months } \\
\hline & Movers & Stayers & Movers & Stayers \\
\hline BLUE-COLLARS & -0.1 & -0.1 & -0.6 & -0.6 \\
\hline WHITE-COLLARS & -0.4 & 0 & -2.4 & 0 \\
\hline
\end{tabular}

\footnotetext{
${ }^{16}$ Unemployment cannot be recorded with certainty in our data-base: self-employment, out-of-the-labor force including retirement (for those in eligible age), moves in the public sector (following a tenured hire), are all compatible with attrition. The observed frequency of moves into self-employment is a little over 7\% of all separations; that of entering the irregular economy, obviously unknown, may be high expecially in the South, but mainly for those who have never been regularly employed before (which is not the case with a closed panel like ours). Notice a similar observation in M.C. Burda and A. Mertens (2001): in Germany only 80\% of all displaced workers are found in socially insured employment 4 years after displacement.

${ }^{17}$ Our estimates are lower than those reported by S. Nickell, P. Jones, G. Quintini (2002) for the U.K. Estimated (hourly) earning losses amount to 10-20\% during the first year from rehiring after the first unemployment spell. As in Italy, losses tend to be higher, the higher the skill level of those involved.
} 


\subsection{Frequency of job changes}

Frequent job switching could be a signal of intense search behaviour, and therefore associated with higher wage growth. On the other hand, too many job-changes could reflect the precariousness of certain positions, characterised by a great deal of uncertainty or little perseverance.

Estimation provides interesting insight also within age groups: among the blue-collars there is no visible impact at any age. Among the white-collars, instead, a certain amount of job-switching has positive effect on wage growth, but only among people in age-groups 1 and 2 (i.e. less than 40 yrs. old): two moves do better than one; three do better than two; but four (or more) flattens the wage profile back to the level of the stayers. Above 40 years of age the positive impact is modest with two moves (6 p.p.) and disappears altogether with more frequent job changes.

Tab. 5 Frequency of job changes: impact on wage growth by occupation and age group

\begin{tabular}{|l|c|c|c|}
\hline $\begin{array}{l}\text { BLUE- } \\
\text { COLLARS }\end{array}$ & 2 MOVES & 3 MOVES & $4>$ MOVES \\
\hline age $20-30$ & 0 & 0 & 0 \\
\hline age $30-40$ & 0 & 0 & 0 \\
\hline age $40-50$ & 0 & 0 & 0 \\
\hline ALL AGES & 0 & 0 & 0 \\
\hline WHITE-COLLARS & & $0.16^{*}$ & 0 \\
\hline age 20-30 & $0.08^{*}$ & 0.12 & 0 \\
\hline age $30-40$ & $0.11^{*}$ & 0 & 0 \\
\hline age 40-50 & 0.06 & $0.14^{*}$ & \\
\hline ALL AGES & $0.09^{*}$ & & \\
\hline
\end{tabular}

\subsection{Initial conditions}

Wage growth in the period 1986-91 may be influenced by initial conditions: unobservable, individual effects like intellectual endowment, entrepreneurial attitudes, risk propensity, and the like. A reasonable proxy is the i-th individual's relative wage in 1986 (INEQ86), i.e. the ratio between $w(i, 86)$ and the average wage 1986 of individuals belonging to the same cell (age $x$ industry x skill level). In principle, one's relative initial wage ought to reflect the relevant individual characteristics. $^{18}$

There is, however, a problem of potential endogeneity of this proxy: 1986 seldom coincides with the beginning of one's working career (safe for very few young workers). Thus, endowed individuals may have a higher initial relative wage, and INEQ86 may be correlated with the residuals. Estimation by instrumental variables could help, but we judge that appropriate instruments are not available. We, therefore, resort to a different strategy consisting of estimating two versions of the wage growth equation: one including INEQ86 among the regressors, the other excluding it. Consider the following outcome: (1) the coefficient estimates are very similar in the two versions ; (2) the overall fitness improves only marginally when INEQ86 is included among the regressors; (3) the residuals are nearly identical. If (1), (2) and (3) are verified together, the implication is that initial conditions do not matter, and that simultaneity bias is not much of a problem here.

The following table displays the outcome of this exercise: we report here also the equations estimated separately for each age group, as initial conditions - not surprisingly - appear to be more relevant at young age than later. Recall that a negative coefficient for INEQ86 is expected by construction as $\mathrm{w}(\mathrm{i}, 86)$ is the denominator of the dependent variable:

\footnotetext{
${ }^{18}$ Farber and Gibbons (1991), among others, find a strong correlation through time between wages and proxies of ability.
} 
Tab. 6 OLS regressions of wage growth with proxy for initial conditions (INEQ86)

\begin{tabular}{|c|c|c|c|c|c|c|}
\hline & Mean & \# & Coeff. INEQ & Std. Err. & $\mathrm{R}^{2 \text { with }}$ INEQ & $\begin{array}{l}\mathrm{R}^{2 \text { withou }} \\
\text { INEQ }\end{array}$ \\
\hline $\begin{array}{l}\text { BLUE C. } \\
\text { age } 20-30\end{array}$ & 1.58 & 7533 & -0.659 & 0.018 & 0.227 & .068 \\
\hline $\begin{array}{l}\text { WHITE C. } \\
\text { age } 20-30\end{array}$ & 1.82 & 2785 & -0.236 & 0.032 & 0.144 & .102 \\
\hline $\begin{array}{l}\text { BLUE C. } \\
\text { age } 30-40\end{array}$ & 1.53 & 7000 & -0.355 & 0.016 & 0.132 & .053 \\
\hline $\begin{array}{l}\text { WHITE C. } \\
\text { age } 30-40\end{array}$ & 1.73 & 4018 & -0.042 & 0.02 & 0.142 & .086 \\
\hline $\begin{array}{l}\text { BLUE C. } \\
\text { age } 40-50\end{array}$ & 1.51 & 5882 & -0.323 & 0.016 & 0.111 & .039 \\
\hline $\begin{array}{l}\text { WHITE C. } \\
\text { age } 40-50\end{array}$ & 1.65 & 2949 & -0.075 & 0.019 & 0.114 & .047 \\
\hline & & & & & & \\
\hline $\begin{array}{l}\text { BLUE C. } \\
\text { all ages }\end{array}$ & & 20415 & -0.426 & 0.009 & 0.157 & 0.069 \\
\hline $\begin{array}{l}\text { WHITE C. } \\
\text { all ages }\end{array}$ & & 9752 & -0.086 & 0.012 & 0.144 & 0.088 \\
\hline
\end{tabular}

Tab. 7 Correlation between residuals of OLS regressions estimated with and without proxy for initial conditions (INEQ86)

\begin{tabular}{|l|r|}
\hline & Correlation coefficient \\
\hline AGE 1 - BLUE C. & 0.920 \\
\hline AGE 2 - BLUE C. & 0.961 \\
\hline AGE 3 - BLUE C. & 0.970 \\
\hline & \\
\hline ALL AGES - BLUE C. & 0.959 \\
\hline & \\
\hline AGE 1 - WHITE C. & 0.991 \\
\hline AGE 2 - WHITE C. & 0.999 \\
\hline AGE 3- WHITE C. & 0.999 \\
\hline & \\
\hline ALL AGES - WHITE C. & 0.995 \\
\hline
\end{tabular}

- the INEQ86 coefficient is significant in all the estimated equations, much larger (in absolute value) in the blue-collars' equations than in the white-collars'. The wage growth of white-collar workers is weakly conditioned by initial pay, while that of the blue-collars is strongly conditioned. ${ }^{19}$ - there are interesting differences across age groups: among young workers (20-30, age-group 1) the INEQ86 coefficient is over twice as large as among older workers, for both white and bluecollars;

- the coefficient estimates are almost identical in the two versions of the white-collars' equations. Among the blue-collars some differences are found in the coefficients of industry dummies and firm-size. They are, instead, very slight for the dummies that catch the effect of inter-firm mobility;

- the correlation of residuals with and without INEQ86 are very high in all estimated equations: the order of magnitude is 0.92-0.97 in the blue-collars' equations, and 0.99 and over in the white-collars'.

All of the above suggest that initial conditions have a negligible impact on the wage profiles of the white-collars. They do, instead, have a modest impact on the blue-collars' profiles. In either case, the influence of initial conditions is slightly higher at young age.

\footnotetext{
${ }^{19}$ A different, legitimate, interpretation is that INEQ86 fails to catch the "right" individual characteristics of people initially hired in white-collar positions;
} 
If initial conditions reflect individual endowments (including educational attainment), then one might expect them to show up especially among white-collars, whose careers have more prospects and variability than those of people confined to manual jobs most of their life. This does not appear to be the case in Italy, for reasons related to the following institutional features: (1) the jobs that we observe are all "regular" working positions, for which social security contributions are paid in full by the employers; (2) the vast majority of these contracts are subject to collective bargaining agreements. The main implication being - for example - that a university graduate in chemical engineering with high honours will be hired at the same conditions as an individual who has barely made it through college in whatever discipline. Their careers will obviously begin to diverge at some point, but a five-year horizon is probably not long enough to comprise this point. ${ }^{20}$ Our story does not imply that the initial employment probabilities will be the same for the two characters: in Italy, as elsewhere, a chemical engineer has better chances than any college graduate in modern literature. But our study is on transitions of people already in employment, not on transitions from school to work. ${ }^{21}$

On the contrary, a young man with a recognized vocational training diploma will be hired as a qualified blue-collar at a higher pay grade than an unskilled individual. Thus, initial conditions do matter for him, and his 1986- relative pay indeed reflects them. This is in line with what is known about the career profiles of manual workers in Italy, highly predetermined by collective bargaining agreements. $^{22}$

\section{Voluntary vs. involuntary job changes (downsizing and redeployment)}

We now turn to the impact of downsizing and workforce redeployment on job changes.

In Italy the 1986-91 period was characterised by a vigorous expansion til 1989, followed by a slow worsening of general economic prospects, which led into the 1991 recession. Since the mid Eighties mergers and acquisitions have frequently taken place among business firms of all sizes, and often workers have been relocated among the partners. Processes of industrial restructuring have also characterized this period, leading to large employment reductions by the big corporations. The bargaining table sometimes yielded agreements between management and unions to help the re-deployment of consistent fractions of the work-force. While the most able workers may refuse re-deployment and do the job-shopping on their own to pre-empt a likely layoff, many will take whatever is offered to them, especially during recessionary years. We expect downsized workers to take wage losses compared to other job changers. In contrast, those who are downsized and contemporaneously redeployed are less likely to loose in the change.

We deal with the issue of voluntary vs. in voluntary job changes by looking at the five-year trend of employment in the firms from which the job-changes originate, and classify them in five groups as follows:

1. Expansion: between 1986 and 1991 the firm has increased its workforce;

2. Constant: no significant variation has occurred in the firm employment;

3. Decline: in the 86-91 period the firm has reduced employment between 10 and $40 \%$;

4. Strong decline: the decline is by more than $40 \%$ of the workforce on payroll;

5. Closeout: the firms has closed in the period.

\footnotetext{
${ }^{20}$ In the near future we shall be able to replicate estimation on a longer observation period, where it is reasonable to expect significant improvements over the results already at hand.

${ }^{21}$ This is not surprising: in Italy economic returns to education are usually found lower than in many countries of the industrialized world (Brunello and Miniaci (1999) report estimates between 4.8 and 5.6\%): one explanation may, in fact, be provided by the nature of collective bargaining institutions.

${ }^{22}$ B. Contini (ed.), Labor mobility and wage dynamics in Italy, Rosenberg-Sellier (2002).
} 
Tab. 8 Movers and stayers by firm of origin

\begin{tabular}{|l|r|r|r|r|r|r|}
\hline & Expanding & Constant & Declining & $\begin{array}{c}\text { Strong } \\
\text { decline }\end{array}$ & Closing & \multicolumn{1}{|c|}{ Total } \\
\hline Movers & 24.7 & 9.6 & 13.1 & 15.9 & 36.7 & 100 \\
\hline Stayers & 52.9 & 23.5 & 20.2 & 3.3 & 0 & 100 \\
\hline
\end{tabular}

Involuntary job changers are all the "downsized" workers, as well as those associated to collective workforce redeployment. The "downsized" ones are simply those who leave a firm that has either closed down, or experienced drastic employment cuts in 1986-91. A different strategy is adopted in order to single out job changes associated to workforce collective redeployment. Following the merger between firms A and B into a new entity C, groups of workers previously on A's and B's payrolls will be transferred directly to the new payroll of $C$ and such collective moves - same origin and destination for all the group members - can be observed in our panel. On the other hand, we assume to be voluntary moves those attributed to workers leaving a firm that expanded its workforce in the observation period.

While it is obvious that this procedure will lead to classify a certain number of false positives as well as false negatives, estimation suggests that, inspite of its built-in arbitrariness, it provides a plausible approximation to reality.

Tab. 9 Downsized workers by age

\begin{tabular}{|l|r|r|r|r|}
\hline & Age $20-30$ & Age $30-40$ & Age $40-50$ & Sample size \\
\hline Movers & 39.0 & 34.1 & 26.9 & 4751 \\
\hline Stayers & 28.1 & 33.7 & 38.2 & 683 \\
\hline
\end{tabular}

Tab. 10 Downsized workers by skill group and percentile ratios of the wage distributions 1986 and 1991 (population $=100)$

\begin{tabular}{|l|r|r|r|r|}
\hline & Mean & \multicolumn{1}{|l|}{ P25 } & $P 50=$ median & \multicolumn{1}{l|}{ P75 } \\
\hline Blue collars & & & & \\
\hline 1986 & 0.96 & 0.97 & 0.97 & 0.95 \\
\hline 1991 & 0.96 & 0.96 & 0.96 & 0.94 \\
\hline White-collars & & & & \\
\hline 1986 & 0.96 & 0.94 & 0.94 & 0.97 \\
\hline 1991 & 0.96 & 0.93 & 0.95 & 0.98 \\
\hline
\end{tabular}

A slight majority of the downsized workers is in young age, while the stayers, i.e. those who get retained inspite of the employment cuts, are somewhat older. Tab. 10 suggests that the downsized workers are generally less skilled than the average within their skill group: their earnings distribution is dominated by the overall distribution both in 1986 and in 1991 . 
Tab. 11 Total wage growth with redeployment and job displacement effects

\begin{tabular}{|c|c|c|c|c|c|c|c|c|c|c|}
\hline & \multicolumn{3}{|c|}{ SMALL } & \multicolumn{3}{|c|}{ MEDIUM } & \multicolumn{4}{|c|}{ LARGE } \\
\hline $\begin{array}{l}\text { BLUE } \\
\text { manufacturing }\end{array}$ & $\begin{array}{r}\text { w- } \\
\text { growth }\end{array}$ & $\begin{array}{l}\text { displ. } \\
\text { effect }\end{array}$ & $\begin{array}{r}\text { re- } \\
\text { depl. }\end{array}$ & $\begin{array}{r}\text { w- } \\
\text { growth }\end{array}$ & $\begin{array}{l}\text { displ. } \\
\text { effect }\end{array}$ & \begin{tabular}{rr|} 
redepl & displ \& \\
oy & redepl.
\end{tabular} & $\begin{array}{r}\text { w- } \\
\text { growth }\end{array}$ & $\begin{array}{l}\text { displ. } \\
\text { effect }\end{array}$ & $\begin{array}{r}\text { Redepl } \\
\text { oy }\end{array}$ & $\begin{array}{l}\text { displ \& } \\
\text { redepl. }\end{array}$ \\
\hline $\begin{array}{l}S \\
M\end{array}$ & $\begin{array}{c}0 \\
-5\end{array}$ & -10 & & $\begin{array}{r}12 \\
4\end{array}$ & & 15 & $\begin{array}{r}22 \\
7\end{array}$ & & 9 & \\
\hline $\mathrm{L}$ & -18 & -33 & & -5 & -16 & & 0 & -11 & -10 & 13 \\
\hline
\end{tabular}

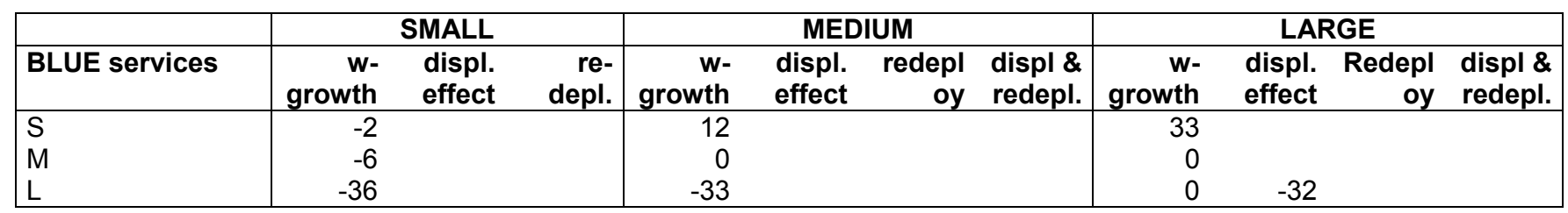

\begin{tabular}{|c|c|c|c|c|c|c|c|c|c|c|c|}
\hline \multirow[b]{2}{*}{$\begin{array}{l}\text { WHITE } \\
\text { manufacturing }\end{array}$} & \multicolumn{3}{|c|}{ SMALL } & \multicolumn{4}{|c|}{ MEDIUM } & \multicolumn{4}{|c|}{ LARGE } \\
\hline & $\begin{array}{r}\text { w- } \\
\text { growth }\end{array}$ & $\begin{array}{l}\text { displ. } \\
\text { effect }\end{array}$ & $\begin{array}{r}\text { re- } \\
\text { depl. }\end{array}$ & $\begin{array}{r}\text { w- } \\
\text { growth }\end{array}$ & $\begin{array}{l}\text { displ. } \\
\text { effect }\end{array}$ & $\begin{array}{r}\text { redepl } \\
\text { oy }\end{array}$ & $\begin{array}{l}\text { displ \& } \\
\text { redepl. }\end{array}$ & $\begin{array}{r}\text { w- } \\
\text { growth }\end{array}$ & $\begin{array}{l}\text { displ. } \\
\text { effect }\end{array}$ & $\begin{array}{r}\text { Redepl } \\
\text { oy }\end{array}$ & $\begin{array}{l}\text { displ \& } \\
\text { redepl. }\end{array}$ \\
\hline $\begin{array}{l}S \\
M\end{array}$ & $\begin{array}{r}-11 \\
0\end{array}$ & 9 & & $\begin{array}{l}12 \\
10\end{array}$ & & & & $\begin{array}{l}33 \\
18\end{array}$ & 3 & -4 & \\
\hline $\mathrm{L}$ & 27 & & & 23 & 5 & -7 & 24 & 14 & 6 & 5 & \\
\hline
\end{tabular}

\begin{tabular}{|c|c|c|c|c|c|c|c|c|c|c|c|}
\hline & \multicolumn{3}{|c|}{ SMALL } & \multicolumn{4}{|c|}{ MEDIUM } & \multicolumn{4}{|c|}{ LARGE } \\
\hline WHITE services & $\begin{array}{r}w- \\
\text { growth }\end{array}$ & $\begin{array}{l}\text { displ. } \\
\text { effect }\end{array}$ & $\begin{array}{r}\text { re- } \\
\text { depl. }\end{array}$ & $\begin{array}{r}\text { w- } \\
\text { growth }\end{array}$ & $\begin{array}{l}\text { displ. } \\
\text { effect }\end{array}$ & $\begin{array}{r}\text { redepl } \\
\text { oy }\end{array}$ & $\begin{array}{l}\text { displ \& } \\
\text { redepl. }\end{array}$ & $\begin{array}{r}\text { w- } \\
\text { growth }\end{array}$ & $\begin{array}{l}\text { displ. } \\
\text { effect }\end{array}$ & $\begin{array}{r}\text { Redepl } \\
\text { oy }\end{array}$ & $\begin{array}{l}\text { displ \& } \\
\text { redepl. }\end{array}$ \\
\hline $\begin{array}{l}S \\
M\end{array}$ & $\begin{array}{r}0 \\
0 \\
28\end{array}$ & $\begin{array}{l}-22 \\
-62\end{array}$ & & $\begin{array}{l}14 \\
11 \\
11\end{array}$ & & & & $\begin{array}{r}62 \\
0 \\
10\end{array}$ & 35 & 24 & \\
\hline
\end{tabular}

In order to catch the effect of downsizing, we use a 0-1 dummy (DOWN) activated if the firm of origin suffered a strong decline in employment or closed in the 86-91 period. While to control for the effect of redeployment we include a 0-1 dummy (GF) activated for job changes involving at least 2 workers from same origin to same destination. Given our sample-population ratio (1:90), observing two individuals moving contemporaneously from the same firm of origin to the same firm of destination implies a collective redeployment as large as between 80 and 280 individuals (average $=180+/-1$ s.d. $=100$ ), as a consequence of corporate transformations, mergers and acquisitions. Finally the effect of expanding firms on wage growth is caught by the 0-1 dummy UP activated for job changes if the firm of origin increased workforce by at least $9 \%$ in the observation period.

The dummy variables DOWN and GF are appropriately interacted..with the $0-1$ job-change $D(i ; k, j)$ variables for the movers. In addition, we introduce DOWN-STAY associated to stayers. Thus the coefficients $\mathrm{D}(\mathrm{i} ; \mathrm{k}, \mathrm{j})^{*} \mathrm{DOWN}$ denote the wage loss that people suffer, whether moving or staying, attributable to the fact that they are on payroll at ailing firms. Likewise $D(i ; k, j)^{*} G F$ denote the wage change due to redeployment, and $\mathrm{D}(\mathrm{i} ; \mathrm{k}, \mathrm{j})^{*} \mathrm{DOWN}{ }^{*} \mathrm{GF}$ the change associated with downsizing followed by collective redeployment.

When DOWN is activated, workers are - as it were - forced by the events to either move or stay. The estimates are reported in Tab. 11: all coefficients (except one) are negatively signed, but we report only those above significance $(t>2)$. There is no detectable effect on the earnings of stayers. The estimates strongly support the hypothesis that downsized workers - manual or white-collars - suffer severe wage losses after the job change. The story is different for workers who get re-deployed: in some cases they too suffer a wage loss, modest compared to downsizing events. At times, however, we observe a wage gain, especially when redeployment occurs in parallel with downsizing events (caught by the interaction DOWN*GF). 


\section{Concluding remarks}

This study aims at establishing how mobility and job displacement affected individual wage growth in the five-year period 1986-91. Here is a summary of our main findings:

(i) the mean initial wage (1986) of the stayers is more than 10 p.p. higher than that of the movers (before moving); the mean final wage (1991) of the stayers is 8.4 p.p. higher than the movers';

(ii) the wage growth of the movers is slightly higher than the stayers'; movers do better than stayers at young age (20-30), but the difference tends to vanish, especially for manual workers as age progresses;

(iii) mover-stayer differentials are larger among white-collars than blue-collars, in line with the higher variance of earnings of the former;

(iv) wage growth attributable to inter-firm mobility is driven by the wage - firm size positive correlation only for blue-collar workers: job-switches from small to large firms yield substantial pay improvements relative to stayers; job switches from large to small size often end up in wage cuts. For the white-collars, instead, job changes in either direction tend to improve one's position relative to stayers;

(v) prolonged unemployment spells have a modest negative impact on the wage growth of white-collar employees (up to 2.5 p.p. for a six-month spell), very slight on the blue-collars'. We find no impact on workers who get rehired by the same firm of origin;

(vi) frequent job-switching has a positive effect on the wage growth of the young and adult white-collars. If job changes become too frequent, however, its positive impact vanishes. No impact is found, instead, on the wage growth of manual workers;

(vii) initial conditions have a modest influence on the wage profile of blue-collar employees; none on the white-collars'.

(viii) workers hit by downsizing events earn lower wages than the rest of their peers, both ante-displacement (1986) and post-displacement (1991). This supports the hypothesis that downsizing hits mainly the least skilled among both manual workers and white-collars;

(ix) the impact of downsizing on wage growth is localized. Somewhat surprisingly, we find no across-the-board impact. Some job changes inflict very substantial wage losses (up to 89 p.p. for moves of white-collars from large to small firms of the service industries), some do not. Manual workers are less damaged from downsizing than the white-collars. Instead, workers who are retained at firms that go through restructuring do not incur in significant wage losses. 


\section{REFERENCES}

Bonjour D., L.Pacelli (1998) "Wage Formation and the Gender Wage Gap: Do Institutions Matter? Italy and Switzerland Compared". U.C.L. Discussion Paper no. 12/98

Brunello, G., Miniaci, Labour Economics (1999)

Burda, M.C., Mertens A., Estimating wage losses of displaced workers in Germany", Labour Economics, (2001)

Contini B., L. Pacelli, C. Villosio (1999) "Short Employment Spells in Italy, Germany and Great Britain: Testing the "Port-of Entry" Hypothesis" CEP Discussion Paper N. 426, June 1999

Contini B., R. Revelli (1997) "Gross flows vs. net flows in the labor market: what is there to be learned", in Labour Economics, no. 4

Contini B:, C. Malpede, L. Pacelli, F. Rapiti (1996) "La mobilità' del lavoro in Italia" in G. Galli ed. "La mobilita' della società' italiana”, SIPI, Roma

Contini, B. and Villosio, C. (1998), 'Analysis of Wage Flexibility and Mobility', Report for the EC, DG V.

Farber, H. S. (1993) "The incidence and cost of job loss: 1982-1991" Brooking Papers on Economic Activity: Microeconomics no. 173-119

Farber, H. S. (1997) "The changing face of job loss in the United States: 1981-1995" Brooking Papers on Economic Activity: Microeconomics 55-128

Flinn C. J. (1986), "Wages and Job Mobility of Young Workers" Journal of Political Economy, vol. 94, no. 3, 1986

Gautier, P.A., van den Berg G., van Ours, J., Ridder, G., „Worker turnover at the firm level and crowding out of lower educated workers", European Economic Review, vol. 46, (2002)

Gibbons, R. and Lawrence F., K. (1991) "Layoffs and Lemons" Journal of Labour Economics 9 351-80

Hartog J., Van Ophem H. (1994) "On-the job search, mobility and wages in the Netherlands: what do we know?", mimeo

Jacobson, L., LaLonde, R., Sullivan, D. 1993 "Earnings Losses of Displaced Workers" The American Economic Review.

Nickell, S, Jones, P., Quintini, G. "A picture of job insecurity facing British Men”, Economic Journal, vol. 112, n. 476 (2002).

Podgursky, M. and Swaim, P. (1987) "Job displacement Earnings Loss: Evidence from the Displaced Worker Survey" Industrial and Labour Relations Review 41 17-29

Prendergast, C., "The provision of incentives in firms", Journal of Economic Literature, vol. XXXVII, March 1999.

Stewart, M. B., Swaffield, J. K. (1998) "Low Pay Dynamics and Transition Probabilities" in "Lowpay and Earnings mobility in Europe" Asplund, Sloane, Theodossiou (eds.), Elgar publisher, 1998 London 